\title{
KONTRIBUSI USAHATANI CENGKEH TERHADAP PENDAPATAN RUMAH TANGGA PETANI DI DESA RAANAN BARU 2, KECAMATAN MOTOLING BARAT
}

\author{
Gogen Klif N. Kumaat \\ Theodora M. Katiandagho \\ Mex L. Sondakh
}

\begin{abstract}
This study aims to find out how much farm income clove and clove farming contribution to total household income of farmers in the New Raanan 2 Village. The study was conducted from March to June 2015. Samples size was 30 respondents using purposive sampling method. Results from this study indicate clove farm income is a source of income which contributes most of all sources of income of farming families. However, in terms of farm income cloves there are several indicators that show the need for increased production and expenditure savings, given harvest once a year and selling prices are volatile. Farmers need to maintain the indicators that have been rated excellent for this, such as vacant devote time to other farms and use clove farm income to education, such as sending children to school.
\end{abstract}

Key words: Contribution of Clove Farm Income, Household Income, South Minahasa

\begin{abstract}
ABSTRAK
Penelitian ini bertujuan mengetahui berapa besar pendapatan usahatani cengkeh dan kontribusi usahatani cengkeh terhadap total pendapatan rumah tangga petani di Desa Raanan Baru 2. Penelitian ini dilaksanakan dari bulan Maret sampai Juni 2015. Sampel yang dipilih sebanyak 30 responden dengan menggunakan metode Purposive Sampling. Hasil dari penelitian ini menunjukkan pendapatan usahatani cengkeh merupakan sumber pendapatan yang berkontribusi paling besar dari semua sumber pendapatan keluarga petani. Akan tetapi, dari segi pendapatan usahatani cengkeh masih terdapat beberapa indikator yang menunjukkan perlu adanya peningkatan produksi dan penghematan pengeluaran, mengingat masa panen setahun sekali dan harga jual yang fluktuatif. Petani perlu mempertahankan indikator-indikator yang telah dinilai baik selama ini, seperti mencurahkan waktu lowong ke usahatani lain dan menggunakan pendapatan usahatani cengkeh ke bidang pendidikan, seperti menyekolahkan anak.
\end{abstract}

Kata kumci: Kontribusi Usahatani Cengkih, Pendapatan Rumah tangga, Minahasa Selatan

\section{PENDAHULUAN}

\section{Latar Belakang}

Cengkeh (Eugenia Caryophyllus) merupakan komoditi strategis yang memiliki peran sosial, budaya, dan ekonomi dalam kehidupan masyarakat
Indonesia. Berdasarkan data dari ACSA (ASEAN clove spice association), Indonesia merupakan negara dengan lahan perkebunan cengkeh terluas di dunia dan Indonesia juga adalah negara produsen sekaligus konsumen cengkeh terbesar di dunia. Tanaman cengkeh merupakan salah satudari 15 komoditas yang diutamakan penanganannya dalam 
pembangunan perkebunan khususnya untuk pemenuhan kebutuhan dalam negeri. Oleh karena itu, komoditas cengkeh diharapkan dapat berkontribusi dalam mengentaskan kemiskinan, membuka lapangan pekerjaan di daerah pedesaan, meningkatkan industri, dan dapat mendorong pengembangan perdagangan dalam dan luar negeri.

Sulawesi Utara sebagai penghasil utama seringkali dijadikan barometer cengkeh nasional, memberikan kontribusi areal seluas $16 \%$ dari luasan nasional. Tanaman cengkeh merupakan tanaman perkebunan yang masih memegang peranan penting dalam perekonomian Kecamatan Motoling Barat. Usahatani cengkeh merupakan jenis perkebunan rakyat yang mendominasi kegiatan usahatani di Desa Raanan Baru 2.

Secara rinci luas lahan dan total produksi cengkeh di setiap desa di Kecamatan Motoling Barat dapat dilihat pada Tabel 1. Tabel 1 menunjukan bahwa total luas lahan cengkeh di Kecamatan Motoling Barat seluas 2.141 ha. Dari 8 desa yang tersebar di Kecamatan Motoling Barat, Desa Raanan Baru 2 merupakan desa dengan tingkat produksi cengkeh tertinggi yaitu $574.080 \mathrm{~kg}$ dan luas lahan yang lebih besar dibandingkan desa lainnya, sehingga dapat disebut bahwa daerah tersebut merupakan wilayah yang sangat potensial dalam pengembangan usahatani cengkeh.

Karakteristik tanaman cengkeh yang hanya bisa dipanen maksimal sebanyak 1 hingga 2 tahun sekali. Banyaknya waktu lowong yang ada memberikan kesempatan bagi petani untuk mencurahkan waktunya pada usaha lain untuk memperoleh pendapatan dan menjaga kesehjateraan keluarganya (Rahardian, 2002).

Pada pengusahaan tanaman cengkeh, hal yang perlu mendapat perhatian khusus adalah masalah pendapatan, karena sangat penting bagi kelangsungan hidup suatu usahatani dan juga bagi petani itu sendiri. Tarigans (2011) menyatakan bahwa pendapatan usahatani cengkeh yang ada saat ini masih kurang mampu mendukung kehidupan petani secara layak. Hal tersebut didukung oleh semakin kecilnya luas areal kepemilikian lahan usahatani cengkeh yang disebabkan oleh perpecahan lahan (fragmentasi) karena pewarisan, serta rendahnya produktifitas dikarenakan nilai tukar cengkeh yang seringkali berfluktuasi.

\begin{tabular}{|c|c|c|c|}
\hline No & Desa & $\begin{array}{l}\text { Luas La- } \\
\text { han } \\
\text { (ha) }\end{array}$ & $\begin{array}{l}\text { Produksi } \\
(\mathrm{Kg})\end{array}$ \\
\hline 1 & $\begin{array}{l}\text { Raanan } \quad \text { Baru } \\
\text { Induk }\end{array}$ & 250 & 390.000 \\
\hline 2 & Raanan Baru 1 & 263 & 410.280 \\
\hline 3 & Raanan Baru 2 & 368 & $\mathbf{5 7 4 . 0 8 0}$ \\
\hline 4 & Tondei Induk & 235 & 366.600 \\
\hline 5 & Tondei 1 & 215 & 335.400 \\
\hline 6 & Tondei 2 & 193 & 301.080 \\
\hline 7 & Toyopon & 261 & 407.160 \\
\hline 8 & Keroit & 356 & 555.360 \\
\hline \multicolumn{2}{|c|}{ Jumlah } & 2.141 & 3.339.960 \\
\hline
\end{tabular}

Sumber: BP3K Kecamatan Motoling Barat, 2013

Menurut Saad (2006), adanya peluang untuk bekerja di luar kegiatan usahatani mendorong petani membuat keputusan untuk mengalokasikan tenaga kerja yang tersedia menjadi lebih efisien. sehingga dapat diasumsikan bahwa dengan tingkat pendapatan usahatani yang rendah, rumah tangga petani akan memaksimalkan pendapatannya dengan jalan mengkombinasikan kegiatannya. Hal tersebut menuntut petani cengkeh agar mampu memiliki strategi khusus untuk dapat menjamin masuknya pendapatan dari sumber-sumber lainnya, seperti usahatani non cengkeh atau profesi di luar usahatani, seperti berdagang, peternakan, industri rumah tangga, perikanan, dan aktivitas lainnya. Strategi tersebut dapat diklasifikasikan sebagai strategi nafkah ganda. Strategi nafkah ganda bertujuan agar petani mampu memenuhi kebutuhan hidup keluarganya tanpa hanya bergantung pada pendapatan hasil usahatani cengkeh.

Dengan diterapkannya strategi nafkah ganda oleh petani cengkeh, menyebabkan terbaginya kontribusi pendapatan rumah tangga tani namun meningkatkan total pendapatan rumah tangga petani cengkeh. Melihat situasi dan kondisi tersebut, maka sangat perlu untuk diteliti mengenai kontribusi usahatani cengkeh terhadap pendapatan 
rumah tangga petani di Desa Raanan Baru 2 Kecamatan Motoling Barat.

\section{Konsep Usahatani}

Usahatani merupakan usaha yang di lakukan oleh petani untuk mendapatkan keuntungan dan kesejahteraan dari pertanian. Jadi usaha tani adalah sebagai organisasi dari alam yang di usahakan oleh petani, keluarga tani, lembaga atau badan usaha lainnya yang berhubungan dengan pertanian untuk memenuhi kebutuhan masyarakat. Menurut Soekartawi (2005), usahatani adalah ilmu yang mempelajari bagaimana seseorang mengalokasikan sumberdaya yang ada secara efektif dan efisien dengan tujuan untuk memperoleh keuntungan yang tinggi pada waktu tertentu. Dikatakan efektif bila petani atau produsen dapat mengalokasikan sumber daya yang dimiliki atau yang dikuasai sebaikbaiknya dan dikatakan efisien bila pemanfaatan sumber daya tersebut menghasilkan keluaran (output) yang melebihi masukan (input).

Ratag dalam Lestari (2002) mengemukakan bahwa ilmu usahatani merupakan ilmu yang mempelajari cara-cara menentukan serta mengkoordinasikan penggunaan faktor- faktor produksi seefektif mungkin sehingga produksi pertanian memberikan pendapatan keluarga petani yang lebih baik. Definisi ini terkandung satu tujuan utama yaitu peningkatan pendapatan keluarga petani. Terdapat 4 unsur esensial dalam kegiatan usahatani (Soekartawi, 2005) yaitu:

1. Tanah, terdiri dari berbagai campuran mineral dan zat organik pengurai. Sebagai lapisan tipis penutup permukaan bumi, serta menjamin pertumbuhan tanaman, hewan dan manusia. Dalam substansi tanah, terdapat empat komponen utama yang mendukung kemungkinan hidupnya tumbuhan, yaitu bahan mineral, bahan organik, air, dan udara.

2. Modal, yaitu barang atau uang yang bersamasama faktor produksi tanah dan tenaga kerja menghasilkan output, yang dalam hal ini yakni hasil pertanian. Sehubungan dengan pemilikan modal, petani diklasifikasikan sebagai petani besar, kaya, berkecukupan dan komersial, serta petani kecil, miskin, tidak berkecukupan, dan tidak komersial. Dalam pengembangan pertanian, ketersediaan modal dalam jumlah cukup, dan te- pat waktu merupakan unsur penting dan strategis. Modal dalam bentuk uang tunai sangat diperlukan bukan hanya untuk membeli sarana produksi pertanian. Misalnya bibit, pupuk, dan lain-lain yang memungkinkan petani melakukan proses produksi yang selanjutnya untuk mendapatkan uang dari hasil penjualan produk usahataninya.

3. Sumber daya manusia, yaitu faktor produksi berupa tenaga kerja. Tenaga kerja manusia terdiri atas tenaga kerja pria, wanita, dan anak-anak. Tenaga kerja dapat mengerjakan semua jenis pekerjaan usahatani berdasarkan tingkat kemampuannya. Akan tetapi, kerja manusia itu dipengaruhi oleh umur, pendidikan, keterampilan, pengalaman, tingkat kecakapan, tingkat kesehatan, dan faktor alam, seperti iklim dan kondisi lahan usahatani. Tenaga kerja dalam usahatani dapat diperoleh dari dalam keluarga, yaitu tenaga kerja yang tidak dibayar upahnya dan tenaga kerja luar keluarga yaitu tenaga kerja yang dibayar upahnya.

4. Manajemen pertanian, yaitu pengelolaan atau ketatalaksanaan pertanian yang sebaik-baiknya secara terencana, terorganisasi atau terkontrol dalam batasan fungsi produksi yaitu mengatur faktor-faktor alam, tenaga kerja dan modal dengan tujuan mencapai keberhasilan usahatani yang akan digarap. Pola usahatani yang kebanyakan masih bersifat tradisional merupakan sebab rendahnya produktifitas.

\section{Karakteristik Rumah Tangga Petani}

Rumah tangga petani menurut Sensus Pertanian (2000) dalam Tarigans (2011) adalah rumah tangga yang sekurang-kurangnya satu anggota rumah tangganya melakukan kegiatan bertani atau berkebun, menanam tanaman kayukayuan, beternak ikan di kolam, karamba maupun tambak, menjadi nelayan, melakukan perburuan atau penangkapan satwa liar, mengusahakan ternak/unggas, atau berusaha dalam jasa pertanian dengan tujuan sebagian atau seluruh hasilnya untuk dijual guna memperoleh pendapatan/keuntungan atas resiko sendiri.

Menurut Shanin dalam Mawikere (2005), terdapat empat karakteristik utama petani:

1. Petani adalah pelaku ekonomi yang berpusat pada usaha milik keluarga. 
2. Selaku petani mereka menggantungkan hidup mereka pada lahan. Bagi petani, lahan pertanian adalah segalanya yakni sebagai sumber yang diandalkan untuk menghasilkan bahan pangan keluarga, harta benda yang bernilai tinggi, dan ukuran terpenting bagi status sosial.

3. Petani memiliki budaya yang spesifik yang menekankan pada pemeliharaan tradisi dan konformitas serta solidaritas sosial mereka kental.

4. Cenderung sebagai pihak selalu kalah (tertindas) namun tidak mudah ditaklukkan oleh kekuatan ekonomi, budaya dan politik eksternal yang mendominasi mereka.

\section{Konsep Ekonomi Rumah Tangga Petani}

Kajian ekonomi rumah tangga petani dilakukan untuk mengetahui strategi dan manajemen kerja yang dilakukan keluarga petani dalam mengalokasikan tenaga dan waktu terhadap sumbersumber ekonomi atau mata pencaharian sekaligus mengatur pendapatan rumah tangga, baik yang berasal dari satu maupun lebih dari satu sumber penghidupan, dalam rangka memenuhi kebutuhan sandang, pangan, dan papan anggota keluarga petani dalam bentuk pengeluaran (Mawikere, 2005). Pencerminan strategi rumah tangga petani untuk hidup sejahtera ditunjukkan oleh alokasi waktu kerja anggota rumah tangga untuk kegiatan mencari nafkah, pekerjaan rumah tangga dan kegiatan lainnya.Tiap kegiatan anggota rumah tangga petani ditujukan untuk mencapai nilai guna menghasilkan kesejahteraan.

Pendapatan rumah tangga petani di pedesaan pada umumnya tidak hanya berasal dari satu sumber, tetapi berasal dari dua atau lebih sumber pendapatan (Wokas, 2002).Ragam sumber pendapatan tersebut diduga dipengaruhi oleh tingkat pendapatan usahatani itu sendiri.Tingkat pendapatan yang relatif rendah mengharuskan anggota rumah tangga petani untuk lebih giat bekerja.Bagi sebagian rumah tangga petani, upaya tersebut tidak hanya menambah curahan jam kerja tetapi juga melakukan kegiatan-kegiatan lainnya.

Beberapa penelitian yang telah ada sebelumnya menunjukan bahwa kontribusi pendapa- tan di luar usahatani berpengaruh nyata terhadap total pendapatan rumah tangga petani, dimana semakin besar kontribusi pendapatan dari luar kegiatan usahatani, maka akan semakin besar pula pendapatan total rumah tangga.Kondisi ini menunjukkan bahwa pekerjaan-pekerjaan di luar kegiatan usahatani memiliki potensi. Pekerjaanpekerjaan di luar usahatani seringkali dijadikan sebagai tambahan penghasilan, sehingga peningkatan pendapatan yang berasal dari luar usahatani akan memberikan dampak besar terhadap peningkatan pendapatan total rumah tangga (Legoh, 2010).

\section{Konsep Strategi Nafkah Ganda dalam Keluarga Petani}

Nafkah (livelihood) secara sederhana didefinisikan sebagai cara dimana orang memenuhi kebutuhan mereka atau peningkatan hidup (Chamberetal dalam Dharmawan, 2001). Dalam pandangan yang sangat sederhana nafkah terlihat sebagai aliran pendapatan berupa uang atau sumber daya yang dapat digunakan oleh seseorang untuk mempertahankan kelangsungan hidupnya. Definisi lain dinyatakan oleh Ellis (2000) dalam Legoh (2010), bahwa nafkah mencakup pendapatan cash (berupa uang tunai) dan in end (pembayaran dengan barang atau hasil bumi).

Terdapat dua basis sumberdaya (resources) yang membentuk strategi nafkah (Hernanto, 2006) yaitu:

1. On-farm, merupakan strategi nafkah yang didasarkan dari sumber hasil pertanian dalam arti luas (pertanian, perkebunan, kehutanan, peternakan, perikanan dan sebagainya).

2. Non-farm, yaitu sumber pendapatan yang berasal dari luar kegiatan pertanian yakni profesi dalam pemerintahan, wirausaha dan sebagainya.

Rumah tangga petani yang menerapkan kedua sumber tersebut sebagai sumber pendapatan tersebut tergolong keluarga petani yang menerapkan nafkah ganda.

Menurut Dharmawan (2001), strategi nafkah sangat ditentukan oleh kemampuan petani dalam mengkombinasikan berbagai sumber nafkah yakni; modal alami (natural capital), modal fisik (physical capital), modal finansial (financial capital), modal sumber daya manusia (human capital) dan modal sosial (social capital). 


\section{Konsep Pengukuran Pendapatan Keluarga Petani}

Hernanto (2006) menerangkan ukuran pendapatan keluarga tani, yaitu penghasilan keluarga sama dengan penjumlahan total pendapatan keluarga dari berbagai sumber. Pendapatan mengacu pada keuntungan (reward, advantages) yang dapat diperoleh rumah tangga dari aktivitas nafkah yang dilakukan rumah tangga.

Pendapatan rumah tangga petani dapat berasal dari pendapatan usahatani dan pendapatan non-usahatani. Persamaan untuk pengukuran pendapatan keluarga tani adalah sebagai berikut:

Dimana:

$$
T I=I F+I N F
$$

TI $=\underset{\text { Total Income }}{\text { Petani }}$ (Total Pendapatan Keluarga

IF = Income Farm (Pendapatan Keluarga dari Usahatani)

$\mathrm{INF}=$ Income Non Farm (Pendapatan Keluarga Petani dari non Usahatani)

\section{Konsep Pendapatan Usahatani}

Mubyarto (2004), menjelaskan bahwa pendapatan adalah hasil pengurangan antara hasil penjualan dengan semua biaya yang di keluarkan mulai dari produksi sampai pada produk tersebut berada pada tangan konsumen. Hasil produksi yang di hasilkan dari setiap jenis usahatani akan di nilai dari biaya yang akan di keluarkan dan penerimaan yang diperoleh. Selisih keduanya merupakan pendapatan petani (Kartosapoetra, 1998). Persamaan yang digunakan adalah sebagai berikut :

$$
\mathbf{I F}=\mathbf{T R}-\mathbf{T C}
$$

\begin{tabular}{|c|c|}
\hline $\bar{F}$ & $\begin{aligned}= & \text { Income Farm (pendapatan } \\
& \text { keluarga dari usahatani) }\end{aligned}$ \\
\hline & Total Revenue (total penerimaan) \\
\hline & Total Costs (biaya total) \\
\hline
\end{tabular}

Dimana:
Untuk memperoleh tingkat pendapatan yang diinginkan maka petani seharusnya mempertimbangkan harga jual dari produksinya, Melakukan perhitungan terhadap semua unsur biaya dan selanjutnya menentukan harga pokok dari usahataninya. Meningkatnya pendapatan maka meningkat pula pengeluaran untuk keperluan rumah tangga dan pembentukan modal. Menurunnya pendapatan akan menurunkan pula pengeluaran untuk konsumsi dan modal.

\section{Konsep Biaya Usahatani}

Biaya merupakan seluruh sumber daya yang digunakan untuk menghasilkan dan memperoleh suatu barang atau jasa (Djojodipuro, 2002). Biaya produksi dapat diklasifikasikan kedalam biaya tetap (fixed cost/FC), biaya variabel (variable cost/VC) dan biaya total (total cost/TC). Fixed cost adalah seluruh biaya yang dikeluarkan untuk memperoleh faktor-faktor produksi yang sifatnya tetap. Variabel cost adalah biaya yang dikeluarkan untuk kegiatan produksi berubah-ubah sesuai perubahan jumlah barang atau jasa yang dihasilkan. Total cost adalah keseluruhan biaya yang dikeluarkan untuk kegiatan proses produksi.

Selain pengklasifikasian di atas biaya atau pengeluaran usahatani dapat digolongkan berdasarkan biaya tunai dan biaya yang diperhitungkan. Biaya tunai adalah biaya yang dikeluarkan secara langsung oleh petani dalam bentuk penggunaan uang untuk membeli sesuatu yang dibutuhkan untuk kegiatan usahatani. Sedangkan biaya yang diperhitungkan adalah biaya yang muncul dari kegiatan usahatani, namun tidak dilakukan pembayaran secara langsung seperti biaya penyusutan, tenaga kerja keluarga, biaya lahan dan lain-lain (Boediono, 2001). Persamaan yang digunakan adalah sebagai berikut :

\section{Dimana :}

$$
\mathrm{TC}=\mathrm{FC}+\mathrm{VC}
$$

TC = Total cost (biaya total)

FC = Fixed Cost (biaya tetap)

VC = Variabel Cost (biaya tidak tetap) 


\section{Kontribusi Pendapatan Usahatani Cengkeh}

Kontribusi memiliki arti sebagai sumbangan atau bagian (Saad, 2006).Sehingga kontribusi pendapatan usahatani cengkeh dapat diartikan sebagai besarnya sumbangan atau bagian dari pendapatan kegiatan usahatani cengkeh yang dijalankan petani terhadap total keseluruhan pendapatan keluarga petani. Sumber pendapatan keluarga petani belum tentu seluruhnya dari kegiatan usahatani cengkeh yang dijalankan, tetapi juga dapat berasal dari kegiatan usahatani lainnya (tanaman pangan, hortikultura, perikanan atau peternakan), atau juga dapat bersumber dari profesi lainnya, seperti bekerja pada institusi pemerintahan atau swasta, kegiatan wirausaha dan profesi padat karya lainnya, bahkan pendapatan dari uang pensiun. Untuk mengetahui besarnya persentase kontribusi usahatani cengkeh terhadap pendapatan petani dapat ditentukan dengan formulasi berikut (Patong dalam Legoh, 2010):

\section{Kontribusi Pendapatan Usahatani Cengkeh}

\section{$=\frac{\text { Pendapatan Usahatani Cengkeh }}{\text { Total Pendapatan Keluarga Petani }} X 100 \%$}

Kontribusi pendapatan usahatani adalah pendapatan yang diterima dari usahatani cengkeh dibagi dengan pendapatan keluarga dan dikalikan $100 \%$, sehingga dapat diketahui seberapa besar kontribusi usahatani cengkeh terhadap pendapatan keluarga (Patong dalam Legoh, 2010).

Usahatani cengkeh dapat dikatakan mempunyai kontribusi yang besar terhadap pendapatan keluarga petani jika keuntungan usahatani cengkeh lebih besar (dominan) dari pada sumber pendapatan lainnya. Dengan mengetahui besaran kontribusi keuntungan usahatani cengkeh bagi pendapatan petani, maka dapat diketahui apakah pendapatan usahatani tersebut sudah atau belum mampu menopang pemenuhan kebutuhan keluarga petani, baik sandang, pangan maupun papan (Legoh, 2010).

\section{Perumusan Masalah}

Berdasarkan pembahasan sebelumnya bahwa seluruh rumah tangga petani cengkeh di Desa Raanan Baru 2 menerapkan strategi nafkah ganda. Mereka tidak mengandalkan satu sumber pendapatan yaitu dari komoditi cengkeh melainkan dari beberapa macam aktivitas kerja, baik usahatani non cengkeh, maupun aktivitas kerja selain usahatani. Keputusan tersebut diambil oleh keluarga petani cengkeh mengingat adanya waktu lowong yang dimiliki petani cengkeh dan harga cengkeh saat ini yang cenderung berfluktuasi cenderung tidak menguntungkan. Penerapan strategi nafkah ganda oleh petani cengkeh, menyebabkan terciptanya beberapa sumber pendapatan yang berkontribusi pada besarnya pendapatan keluarga petani. Melihat kenyataan tersebut, maka yang menjadi perumusan masalah dalam penelitian ini adalah seberapa besar pendapatan petani cengkeh dan berapa besar kontribusi pendapatan usahatani cengkeh terhadap pendapatan rumah tangga petani di Desa Raanan Baru 2.

\section{Tujuan dan Manfaat Penelitian}

Tujuan dari penelitian ini adalah untuk melihat berapa besar pendapatan usahatani cengkeh dan kontribusi dari usahatani cengkeh terhadap total pendapatan rumah tangga petani cengkeh di Desa Raanan Baru 2 dari berbagai sumber kegiatan usahatani dan diluar kegiatan usahatani.

Adapun manfaat dari penelitian ini adalah dapat memberikan informasi mengenai keadaan usahatani cengkeh di Desa Raanan Baru 2 bagi pemerintah setempat serta Dinas Pertanian Kabupaten Minahasa Selatan, sehingga dapat disusun suatu program atau kebijakan yang mampu membantu petanidalam mengelola usahatani cengkeh dengan semaksimal mungkin agar bisa mendapatkan tingkat keuntungan yang maksimum sehingga terjadi peningkatan kesejahteraan keluarga petani cengkeh. 


\section{METODOLOGI PENELITIAN}

\section{Tempat dan Waktu Penelitian}

Penelitian ini dilaksanakan di Desa Raanan Baru 2. Hal ini dikarenakan desa tersebut merupakan daerah produksi cengkeh terbesar di Kecamatan Motoling Barat, serta sebagian besar penduduk desa berprofesi sebagai petani cengkeh, sehingga desa tersebut dapat mewakili penelitian mengenai kontribusi usahatani cengkeh terhadap pendapatan rumah tangga petani. Waktu penelitian selama 4 bulan, dari bulan Februari sampai bulan Mei 2015.

\section{Metode Pengumpulan Data}

Metode yang digunakan dalam penelitian ini adalah metode survey. Data yang digunakan dalam penelitian ini adalah data primer dan data sekunder. Data primer diperoleh dengan menggunakan teknik wawancara langsung kepada petani cengkeh sebagai responden, dengan menggunakan daftar pertanyaan (kuesioner) sebagai alat bantu dalam pengumpulan data. Sedangkan data sekunder diperoleh dari kantor Desa Raanan Baru 2, kantor BP3K Kecamatan Motoling Barat, dan Dinas Pertanian Kabupaten Minahasa Selatan.

\section{Metode Pengambilan Sampel}

Pengambilan sampel dilakukan dengan cara sengaja (purposife random sampling). Dengan jumlah sampel sebanyak 30 rumah tangga petani cengkeh dari jumlah 105 rumah tangga petani cengkeh di Desa Ranaan Baru 2.

\section{Konsep Pengukuran Variabel}

1. Karakteristik petani responden :

a. Umur: usia sejak responden dilahirkan sampai saat menjadi responden dalam penelitian (tahun).

b. Tingkat Pendidikan Formal: lamanya responden duduk di bangku sekolah formal (SD/SMP/SMA/Perguruan tinggi)

c. Jumlah Tanggungan Keluarga: menunjukan jumlah anggota keluarga dalam rumah tangga responden (orang)

d. Pengalaman bertani: yaitu lamanya responden bekerja sebagai petani cengkeh (tahun).
2. Pendapatan keluarga petani yang bersumber dari keuntungan usahatani cengkeh setiap tahun, mencakup :

a) Total produksi cengkeh yang dihasilkan petani pada panen cengkeh tahun $2013(\mathrm{Kg})$

b) Harga jual cengkeh, yaitu harga cengkeh yang berlaku di tingkat petani $(\mathrm{Rp} / \mathrm{kg})$.

c) Penerimaan usahatani cengkeh, merupakan sejumlah uang yang diterima petani sebagai hasil penjualan cengkeh. Total penerimaan diperoleh dari perkalian antara total produksi dan harga (Rp).

d) Biaya produksi yang dikeluarkan petani sejak tahap budidaya cengkeh hingga pengolahan menjadi cengkeh kering (Rp) dalam 1 tahun, meliputi:

- Biaya tetap $(\mathrm{Rp})$ yang terdiri dari pajak dan biaya penyusutan alat

- Biaya variabel (Rp), yang terdiri dari pengadaan pupuk, pestisida, biaya tenaga kerja, dan biaya pemasaran (transportasi)

e) Keuntungan usahatani cengkeh, merupakan besaran pendapatan petani dari kegiatan usahatani cengkeh. Keuntungan usahatani merupakan selisih antara total penerimaan dan total biaya produksi (Rp/tahun).

3. Pendapatan keluarga petani yang bersumber dari keuntungan usahatani selain usahatani cengkeh (Rp/Tahun).

4. Pendapatan keluarga petani diluar kegiatan usahatani, yaitu sejumlah pendapatan petani yang diperoleh dari kegiatan selain usahatani, seperti profesi dalam institusi pemerintahan, swasta, kegiatan wirausaha atau profesi lainnya (Rp/tahun).

5. Total pendapatan keluarga petani, yaitu keseluruhan pendapatan keluarga petani yang diperoleh dari kegiatan usahatani cengkeh, usahatani selain cengkeh, serta pendapatan diluar usahatani (Rp/tahun).

6. Kontribusi pendapatan, yaitu persentase sumbangan atau bagian dari setiap sumber pendapatan (usahatani cengkeh, usahatani non cengkeh dan profesi selain usahatani) dari total keseluruhan pendapatan rumah tangga petani $(\%)$. 


\section{Analisis Data}

Data yang diperoleh dalam penelitian ini akan dianalisis dengan menggunakan metode deskriptif dan hasil penelitian akan disajikan dalam bentuk tabel. Sedangkan untuk mengetahui total pendapatan keluarga petani, analisis data akan menggunakan analisis total pendapatan dengan formulasi:

$$
T I=I F c+I F n c+I N F
$$

Dimana:

TI = Total Pendapatan Keluarga Petani

$\mathrm{IFc}=$ Pendapatan Keluarga dari Usahatani Cengkeh

IFnc = Pendapatan Keluarga Petani dari Usahatani non Cengkeh

INF = Pendapatan Keluarga Petani dari Kegiatan non Usahatani

Sedangkan untuk mengetahui besarnya persentase kontribusi usahatani cengkeh terhadap total pendapatan rumah tangga petani dapat ditentukan dengan formulasi berikut:

\section{Kontribusi Pendapatan Usaha tani Cengkeh}

$$
=\frac{\text { Pendapatan Usahatani Cengkeh }}{\text { Total Pendapatan Keluarga Petani }} \times 100 \%
$$

\section{PEMBAHASAN}

\section{Deskripsi Wilayah Penelitian}

\section{Keadaan Topografi}

Desa Raanan Baru Dua terletak pada Kecamatan Motoling Barat dengan luas wilayah $750 \mathrm{ha} / \mathrm{m}^{2}$. Batas-batas wilayah desa Raanan Baru Dua adalah sebagai berikut.

1. Sebelah Utara : Kecamatan Motoling

2. SebelahTimur : Desa Raanan Baru

3. Sebelah Selatan : Desa Raanan Baru

4. Sebelah Barat : Desa Tondey Dua

\section{Keadaan Penduduk}

Data demografis Desa Raanan Baru Dua pada tahun 2013 memiliki jumlah penduduk 740 terdiri dari laki-laki 428 dan perempuan 312 .

\section{Tingkat Pendidikan}

Pembangunan pendidikan menjadi salah satu program prioritas baik pemerintah desa, maupun masyarakat secara umum, karena sektor ini akan menjadi penentu kualitas Sumber Daya Manusia yang terdapat di desa (Soekartawi, 2005). Tabel 2 menunjukan jumlah penduduk menurut tingkat pendidikan.

Tabel 2. Jumlah Penduduk Menurut Tingkat Pendidikan

\begin{tabular}{ccc}
\hline $\begin{array}{c}\text { Tingkat } \\
\text { Pendidikan }\end{array}$ & $\begin{array}{c}\text { Jumlah } \\
\text { Penduduk } \\
\text { (Jiwa) }\end{array}$ & $\begin{array}{c}\text { Persentase } \\
(\%)\end{array}$ \\
\hline SD & 155 & 26,8 \\
SMP & 216 & 37,4 \\
SMA/SMK & 162 & 28,0 \\
PerguruanTinggi & 44 & 7,6 \\
\hline Jumlah & $\mathbf{5 7 7}$ & $\mathbf{1 0 0}$ \\
\hline
\end{tabular}

Sumber : Data Desa Raanan Baru 2, 2013

Berdasarkan Tabel 2 dapat dilihat bahwa jenjang pendidikan tertinggi di Desa Raanan Baru Dua adalah perguruan tinggi, tetapi jumlahnya masih tergolong rendah yaitu 44 jiwa atau 7,6\%. Sedangkan jumlah penduduk terbesar berada pada jenjang SMP, yaitu 216 jiwa atau 37,4 \%. Melalui data diatas dapat dikatakan wajib belajar di Desa Raanan Baru Dua berjalan dengan baik dan cukup berhasil. Data diatas belum termasuk penduduk yang belum berusia sekolah.

\section{Mata Pencaharian Penduduk}

Adapun mata pencaharian penduduk desa Raanan Baru Dua cukup beragam, yaitu sebagai petani, buruh tani, PNS/Guru, pedagang, karyawan swasta, sopir, dan tukang bangunan.

Tabel 3 menunjukan jumlah penduduk menurut mata pencaharian. 
Berdasarkan Tabel 3 dapat dilihat bahwa, sebagian besar penduduk di Desa Raanan Baru Dua bekerja di sektor pertanian, yaitu sebesar 330 jiwa atau 59,4 \% sedangkan penduduk yang berprofesi sebagai buruh tani sebanyak 165 orang atau 29,7\% dari total keseluruhan penduduk.

Tabel 3. Jumlah Penduduk Menurut Mata Pencaharian

\begin{tabular}{ccc}
\hline $\begin{array}{c}\text { Mata } \\
\text { Pencaharian }\end{array}$ & $\begin{array}{c}\text { Jumlah } \\
\text { Penduduk } \\
\text { (Orang) }\end{array}$ & $\begin{array}{c}\text { Persentase } \\
(\mathbf{\%})\end{array}$ \\
\hline Petani & 330 & 59,45 \\
Buruh Tani & 145 & 26,12 \\
PNS/Guru & 39 & 7,02 \\
Tukang & 24 & 4,32 \\
Pedagang & 11 & 1,98 \\
Karyawan & 6 & 1,08 \\
Swasta & & $\mathbf{1 0 0}$
\end{tabular}

Sumber: Kantor Desa Raanan Baru Dua, 2013

\section{Karakteristik petani responden}

\section{Umur Responden}

Umur petani akan mempengaruhi produktivitas kerja atau peranannya dalam pengambilan keputusan dari berbagai alternatif pekerjaan yang dilakukan.

Tabel 4. Jumlah dan Persentase Petani Responden Menurut Golongan Umur di Desa Raanan Baru Dua

\begin{tabular}{ccc}
\hline $\begin{array}{c}\text { Umur Petani } \\
\text { (tahun) }\end{array}$ & $\begin{array}{c}\text { Jumlah Petani } \\
\text { Responden } \\
\text { (orang) }\end{array}$ & $\begin{array}{c}\text { Presentase } \\
(\mathbf{\%})\end{array}$ \\
\hline$<40$ & 6 & $20 \%$ \\
$41-50$ & 9 & $30 \%$ \\
$51-60$ & 10 & $33.33 \%$ \\
$>61$ & 5 & $16.66 \%$ \\
\hline Total & 30 & $100 \%$ \\
\hline
\end{tabular}

Sumber : Data primer yang telah diolah, 2013

Umur petani memiliki hubungan dengan kemampuan petani dalam bekerja. Jika ditintau dari segi fisik, semakin tua umur seorang setelah melewati batas umur tertentu, maka semakin berkurang kemampuan untuk bekerja. Data responden menurut umur dapat dilihat melalui Tabel 4.

Dari Tabel 4 menunjukan umur petani responden yang memiliki persentase terbesar adalah kelompok umur 51- 60 tahun yaitu sebesar $33.33 \%$ dan kelompok umur $>61$ tahun memiliki persentase terkecil yaitu $16.66 \%$.

\section{Tingkat Pendidikan}

Pendidikan sangat berperan penting dalam menciptakan perubahan-perubahan dalam kehidupan masyarakat. Pendidikan juga dapat memberikan pemahaman akan baik dan buruk, garis pemisah antara sesuatu yang boleh dan yang tidak boleh dilakukan.

Pendidikan merupakan salah satu faktor yang menentukan produktifitas kerja, sikap serta kemampuan seseorang dalam berfikir dan bertindak. Berdasarkan hasil penelitian, tingkat pendidikan responden bervariasi mulai dari tingkat Sekolah Dasar (SD), Sekolah Menengah Pertama (SMP), Sekolah Menengah Keatas (SMA), dan Perguruan Tinggi (S1) yang dapat dilihat melalui Tabel 5.

Tabel 5. Jumlah dan Persentase Petani Responden Menurut Tingkat Pendidikan di Desa Raanan Baru dua

\begin{tabular}{lll}
\hline Pendidikan & $\begin{array}{c}\text { Jumlah petani } \\
\text { responden } \\
\text { (orang) }\end{array}$ & $\begin{array}{c}\text { Presentase } \\
(\%)\end{array}$ \\
\hline SD & 15 & $50 \%$ \\
SMP & 4 & $13,33 \%$ \\
SMA & 11 & $36,66 \%$ \\
Perguruan & 1 & $3,33 \%$ \\
Tinggi (S1) & & \\
\hline Total & $\mathbf{3 0}$ & $\mathbf{1 0 0 \%}$ \\
\hline
\end{tabular}

Sumber: Hasil Pengolahan Data, 2013

Tabel 5 menunjukkan jumlah responden petani menurut tingkat pendidikan dan yang paling banyak adalah petani yang tingkat pendidikan SD yaitu sebanyak 15 orang atau $50 \%$. Untuk responden petani yang berpendidikan SMP dengan jumlah 4 orang atau $13,33 \%$, untuk responden yang berpen- 
didikan SMA sederajat dengan jumlah 11 orang atau 36,66 \%, sedangkan untuk responden petani yang berpendidikan $S 1$ berjumlah 1 orang atau 3,33 $\%$. Hal ini menunjukan adanya kesadaran masyarakat akan pentingnya pendidikan.

\section{Jumlah Tanggungan Keluarga}

Hasrat petani untuk mencapai taraf kehidupan yang lebih baik bagi keluarga, dalam banyak hal merupakan dorongan yang efektif untuk mempertinggi hasil usahataninya. Keluarga merupakan unit masyarakat terkecil dan biasanya terdiri dari beberapa orang yaitu ayah, ibu, dan anak-anak. Jumlah anggota keluarga merupakan salah satu faktor penunjang keberhasilan dalam berusahatani. Dibawah ini dapat di lihat jumlah tanggungan keluarga dari petani cengkeh di Desa Raanan Baru Dua.

\begin{tabular}{ccc}
\multicolumn{3}{c}{ Tabel 6. Jumlah Tanggungan Keluarga } \\
\hline $\begin{array}{c}\text { Jumlah } \\
\text { Tanggungan } \\
\text { (orang) }\end{array}$ & $\begin{array}{c}\text { Jumlah } \\
\text { Petani } \\
\text { (orang) }\end{array}$ & $\begin{array}{c}\text { Persentase } \\
\mathbf{( \% )}\end{array}$ \\
\hline $2-3$ & 14 & 46,66 \\
$4-5$ & 15 & 50 \\
$>6$ & 1 & 3,33 \\
\hline Total & $\mathbf{5}$ & $\mathbf{1 0 0}$ \\
\hline
\end{tabular}

Sumber : Diolah dari data primer, 2013

Dari Tabel 6, dapat dilihat bahwa dari 30 orang responden petani ada 14 responden petani atau 46,66 \% yang memiliki jumlah tanggungan 2-3 orang, 15 orang petani responden atau 50\% memiliki jumlah tanggungan 4-5 orang, dan 1 orang petani responden atau 3,33\% yang memiliki tanggungan $>6$ orang. Umumnya jumlah anggota keluarga yang terhitung dalam jumlah tanggungan ini membantu dalam hal penyediaan tenaga kerja.

\section{Pengalaman Bertani}

Pengalaman petani mempengaruhi produktivitas hasil panen karena dari pengalaman dapat diukur tingkat produktivitas petani. Pengalaman usahatani yang dimiliki oleh petani cengkeh akan mempengaruhi kegiatan dan keahliannya dalam melakukan usahatani cengkeh ini serta mempelajari teknik baru. Pengalaman petani cengkeh di Desa Raanan Baru Dua sudah tergolong lama dan turun-temurun dikarenakan usaha tani cengkeh merupakan usaha tani unggulan di desa Raanan Baru Dua. Pengalaman petani cengkeh rata-rata berkisar di antara 10-40 tahun.

\section{Pendapatan Keluarga Petani yang Bersumber Dari Keuntungan Usahatani Cengkeh}

\section{Total Produksi Cengkeh}

Salah satu tujuan usahatani adalah dicapainya produksi dan pendapatan yang tinggi. Produksi merupakan hasil yang diperoleh petani pada saat panen dengan proses produksi yang menggunakan sumber daya sehingga dapat menghasilkan sesuatu berupa barang, jasa ataupun keduanya. Panen cengkeh umumnya terjadi setahun sekali dan siklusnya berganti setiap tahun antara panen besar dan panen kecil. Berdasarkan penelitian rata-rata produksi cengkeh sebesar $1188,66 \mathrm{~kg}$ dari luas lahan rata-rata 1,85 ha.

\section{Harga Jual Cengkeh}

Harga merupakan persetujuan antara pembeli dan penjual dalam menilai suatu produk tertentu (Soemarsono, 1990). Untuk harga cengkeh yang masuk ke petani pada tahun 2013 berkisar antara Rp 110.000 - Rp 130.000 per kilogram cengkeh kering. Harga jual rata-rata Rp $117.966,66 / \mathrm{kg}$ untuk tahun 2013.

\section{Penerimaan Usahatani Cengkeh}

Penerimaan usahatani cengkeh, merupakan sejumlah uang yang diterima petani sebagai hasil penjualan cengkeh. Total penerimaan diperoleh dari perkalian antara total produksi dan harga. Berdasarkan data penelitian rata-rata penerimaan sebesar Rp 138.697.333,3

\section{Biaya Produksi}

Biaya produksi adalah semua biaya yang di keluarkan petani dalam suatu proses produksi selama setahun. Dalam hal ini produksi cengkeh yang terdiri dari biaya tetap dan biaya variabel. 


\section{a. Biaya tetap}

Biaya tetap adalah biaya yang tidak tergantung dari besar kecilnya volume produksi. dalam penelitian ini, biaya tetap terdiri dari pajak lahan dan biaya penyusutan. Biaya pajak yang diteliti bervariasi tergantung dari besarnya luasan lahan dan jauh dekatnya lahan terhadap pemukiman penduduk, dimana semakin dekat pemukiman maka biaya pajak lahan semakin besar dan demikian sebaliknya. Biaya pajak rata-rata per tahun Rp. 64.316,66

Untuk biaya penyusutan di peroleh berbagai macam alat yaitu tangga, tali, karung, sarung, terpal, saringan/ayahan. Rata-rata usia ekonomis untuk alat terpal, dan saringan/ayahan bekisar 3 tahun. Untuk alat tangga, tali, karung, dan sarung tidak di hitung biaya penyusutan karna hanya sekali pakai. Rata-rata penyusutan alat adalah $\mathrm{Rp}$ 488.555,6

\section{b. Biaya variabel}

Biaya variabel pada usahatani cengkeh terdiri dari sarana produksi dan biaya tenaga kerja.

\section{- Benih}

Pada umumnya petani di desa Raanan Baru Dua dalam usahatani cengkeh menggunakan benih hasil dari tanaman itu sendiri. Dan untuk penanaman cengkeh sudah dilakukan sejak 15 tahun yang lalu. Sehingga biaya sarana produksi benih sudah tidak di perhitungkan lagi.

\section{- Pupuk}

Dalam upaya peningkatan produksi cengkeh dan tanaman selain cengkeh pemupukan merupakan hal penting yang harus diperhatikan. Dari hasil penelitian ini ditemukan bahwa hanya ada beberapa petani responden yang melakukan pemupukan di karenakan kurangnya pengetahuan petani akan jenis pupuk yang benar-benar akan berguna bagi tanaman cengkeh. Rata-rata biaya pemupukan adalah Rp 443.750.

\section{- Pestisida/Herbisida}

Petani responden di desa ini pada umumnya tidak menggunakan pestida dan herbisida pada upaya pemberantasan hama dan penyakit tanaman cengkeh.

\section{- Biaya Tenaga Kerja}

Tenaga kerja usahatani cengkeh biasanya digunakan untuk kegiatan pemeliharaan, panen/pemetikan, pengangkutan, dan pengeringan. Untuk kegiatan pemeliharaan mengunakan tenaga kerja luar keluarga. Dengan biaya tenaga kerja Rp 175.000 per hari untuk pembersihan lahan dengan menggunakan mesin paras. Dan Rp 175.000 per hari untuk tenaga kerja pembasmi hama ulat. Untuk biaya pemupukan di kenakan biaya sebesar Rp 100.000 per hari. Untuk pemetikan di hitung Rp 5000 per liter namun konsumsi dan rokok di tanggung oleh pemetik. Jika konsumsi dan rokok di tanggung oleh petani maka biaya per liter adalah Rp 3000. Dalam penelitian ini sebagian petani yang membayar biaya pemetikan dengan tanggungan konsumsi dan rokok di konfersikan bersama petani yang membayar biaya pemetikan tanpa tanggungan dengan biaya sebesar Rp 5000 per liter, karena alasan petani kesulitan mengingat rincian biaya konsumsi dan rokok. Untuk biaya pengawasan dan biaya penjemuran dan pengemasan menggunakan tenaga kerja dalam keluarga dan di beri nilai masing-masing $\mathrm{Rp}$ 100.000 per hari. Maka rata-rata semua biaya tenaga kerja mulai dari pembersihan lahan sampai pada pengolahan menjadi cengkeh kering ialah sebesar Rp 48.125.983,33.

\section{- Angkutan}

Angkutan yang biasanya digunakan untuk mengeluarkan hasil produksi cengkeh dari kebun ke rumah petani dengan menggunakan transportasi traditional roda sapi atau ojek motor, tergantung dari akses jalan yang harus di tempu. Dan biayanya pun tergantung dari jarak rumah ke kebun, untuk jarak yang lebih jauh dibayarkan lebih mahal. Ratarata biaya angkutan adalah sebesar Rp 1.848.276, 
Pendapatan Usahatani Cengkeh

Pendapatan usahatani cengkeh, merupakan besaran pendapatan petani dari kegiatan usahatani cengkeh. Pendapatan usahatani merupakan selisih antara total penerimaan dan total biaya produksi (Rp/tahun). Rata-rata pendapatan usahatani cengkeh di desa Raanan Baru Dua adalah sebesar Rp 90.571.350,-

Pendapatan Keluarga Petani yang Bersumber dari Usahatani Selain Usahatani Cengkeh (Rp/Tahun)

Selain dari usahatani cengkeh, pendapatan rumah tangga petani juga diperoleh dari beberapa sumber usahatani lain. Dari hasil wawancara dengan petani responden, rata-rata pendapatan petani dari sumber lain dapat dilihat pada Tabel 7. Tabel 7 menunjukan total pendapatan yang diperoleh petani di luar usahatani cengkeh. Rata-rata pendapatan petani dari sumber usahatani selain cengkeh adalah Rp 12.475.000,-

Tabel 7. Sumber pendapatan rumah tanggga petani selain usahatani cengkeh

\begin{tabular}{llr}
\hline No & \multicolumn{1}{c}{ Jenis Usahatani } & \multicolumn{1}{c}{$\begin{array}{c}\text { Pendapatan } \\
(\mathrm{Rp})\end{array}$} \\
\hline 1 & Kelapa & 50.600 .000 \\
2 & Aren & 160.000 .000 \\
3 & Jagung & 43.950 .000 \\
4 & sawah & 46.500 .000 \\
5 & Rica & 29.700 .000 \\
6 & Umbi-umbian & 33.600 .000 \\
\hline & Total & $\mathbf{3 7 4 . 2 5 0 . 0 0 0}$ \\
\hline & Rata-rata & $\mathbf{1 2 . 4 7 5 . 0 0 0 , -}$ \\
\hline
\end{tabular}

Sumber: Hasil Pengolahan Data, 2013

\section{Pendapatan Keluarga Petani Diluar} Kegiatan Usahatani

Adapun pendapatan rumah tangga petani cengkeh yang berasal dari pendapatan non usahatani atau pendapatan yang diperoleh di luar kegiatan usahatani. Tabel 8 menunjukkan bahwa rata-rata pendapatan responden dari jenis pekerjaan selain di bidang pertanian adalah sebesar Rp 31.206.896,-
Tabel 8. Pendapatan Responden berdasarkan Jenis Pekerjaan selain di Bidang Pertanian

\begin{tabular}{llr}
\hline No & Jenis Pekerjaan & \multicolumn{1}{r}{ Pendapatan $(\mathrm{Rp})$} \\
\hline 1 & PNS & 113.000 .000 \\
2 & Pedagang & 82.000 .000 \\
3 & Buruh & 116.000 .000 \\
4 & Tukang & 192.000 .000 \\
5 & Sopir & 129.400 .000 \\
6 & Ternak & 89.000 .000 \\
7 & Karyawan Swasta & 183.600 .000 \\
\hline & Total & $\mathbf{9 0 5 . 0 0 0 . 0 0 0}$ \\
\hline & Rata-rata & $\mathbf{3 1 . 2 0 6 . 8 9 6}$ \\
\hline
\end{tabular}

\section{Total Pendapatan Keluarga Petani Cengkeh}

Pendapatan total rumah tangga petani cengkeh terdiri dari seluruh pendapatan yang diperoleh dari usahatani cengkeh, usahatani lain, dan dari non usahatani. Dari hasil penelitian, dari seluruh pendapatan petani baik dari pendapatan usahatani dan non usahatani porsi yang paling tinggi adalah pendapatan usahatani cengkeh. Rata-rata total pendapatan keluarga petani cengkeh adalah sebanyak Rp 133.213.016,-

\section{Kontribusi Pendapatan Usahatani Cengkeh Terhadap Total Pendapatan Keluarga Petani}

Kontribusi adalah sumbangan atau bagian, kontribusi usahatani cengkeh terhadap pendapatan keluarga petani adalah besarnya sumbangan atau bagian pendapatan dari usahatani cengkeh terhadap keseluruhan pendapatan petani dari usahataninya. Besarnya kontribusi pendapatan usahatani cengkeh dapat dilihat dari Tabel 9. Tabel 9 menunjukkan bahwa kontribusi pendapatan tertinggi yang berasal dari usahatani cengkeh dibandingkan lainnya. 
Tabel 9. Kontribusi Pendapatan Rata-rata Usahatani Cengkeh terhadap Pendapatan Keluarga Petani.

\begin{tabular}{ccc}
\hline $\begin{array}{c}\text { Sumber Penda- } \\
\text { patan }\end{array}$ & $\begin{array}{c}\text { Pendapatan } \\
\text { (dalam rata-rata } \\
\text { Rp) }\end{array}$ & $\begin{array}{c}\text { Persentase } \\
\mathbf{\%}\end{array}$ \\
\hline Usahatani & $90.571 .350,-$ & $67,98 \%$ \\
Cengkeh & & \\
Usahatani Lain & $12.475 .000,-$ & 9,36 \\
Di luar usahatani & $31.206 .896,-$ & 22,64 \\
\hline Jumlah & $133.213 .016,-$ & $\mathbf{1 0 0}$ \\
\hline
\end{tabular}

\section{KESIMPULAN DAN SARAN}

\section{Kesimpulan}

1. Dari hasil penelitian, rata-rata jumlah pendapatan petani cengkeh terhadap usahatani cengkeh adalah sebesar Rp 90.571.350,-

2. Kontribusi pendapatan usahatani cengkeh terhadap pendapatan keluarga petani di Desa Raanan Baru Dua sebesar 67,98\%.

3. Usahatani cengkeh di Desa Raanan Baru Dua masih menjadi sumber pendapatan utama bagi petani untuk memenuhi kebutuhan keluarga petani.

\section{Saran}

1. Dengan ketersediaan lahan yang tergolong cukup luas, produksi cengkeh masih biasa lebih di tingkatkan lagi dengan penggunaan pupuk yang tepat, peremajaan tanaman cengkeh, pemberantasan hama dan penyakit. Pemerintah dan Dinas Pertanian perlu memberikan penyuluhan pada petani.

2. Mengingat usahatani cengkeh di Desa Raanan Baru Dua memiliki kontribusi yang lebih besar dari usahatani lain dan pendapatan di luar kegiatan usahatani, maka pemerintah perlu menjaga kestabilan harga jual cengkeh agar petani mendapatkan harga yang layak.

3. Disarankan kepada petani untuk selalu melakukan penghematan pengeluaran, dikarenakan harga cengkeh yang fluktuatif menjadikan pendapatan petani tidak selalu tinggi, dan juga mengingat untuk biaya produksi panen selanjutnya.

\section{DAFTAR PUSTAKA}

Adiwilaga. 2012. Ilmu Usahatani. Penerbit Alumni. Bandung.

Boediono. 2001. Ekonomi Mikro. Penerbit BPFE. Yogyakarta.

Djojodipuro. 2002. Teori Harga. Lembaga Penerbit Fekon UI Press. Jakarta.

Dharmawan. 2001. Startegi Nafkah Ganda Petani Tanaman Perkebunan. Penerbit Aksara Ilmu. Bandung

Hernanto. 2006. Konsep Ilmu Usahatani. Penerbit Swadaya. Jakarta.

Kartasapoetra. 1998. Hukum Tanah Edisi Revisi. Rineka Cipta. Jakarta.

Legoh. 2010. Kontribusi Keuntungan Usahatani Kelapa Terhadap Pendapatan Keluarga di Desa Naha dan Desa Beha Kecamatan Tabukan Utara. Skripsi Fakultas Pertanian Universitas Sam Ratulangi. Manado.

Mawikere.2005. Analisis Pendapatan dan Pengeluaran Rumah Tangga Petani Kelapa Di Kecamatan Kalawat. Skripsi Fakultas Pertanian Universitas Sam Ratulangi. Manado.

Mubyarto. 2004. Pengantar Ekonomi Pertanian. Penerbit PLP3ES Press. Jakarta.

Rahardian. 2002. Prospek Pengembangan Cengkeh Kering.Jurnal Ilmiah Balai Penelitian Tanaman Tahunan Volume 17 nomor 3 Tahun Kelima Hal 19 - 22. Medan.

Lestari.2002.Dasar-Dasar Pengelolaan Usahatani.Jurnal Ilmiah Fakultas PertanianUniversitas Sumatera Utara. Medan.

Saad.2006. Kontribusi Pengembangan Potensi Pertanian Daerah terhadap Kesejahteraan Masyarakat Pedesaan. PT Eresco. Bandung. 
Soekartawi.2005. Analisis Usahatani Edisi Revisi. Universitas Indonesia Press. Jakarta.

Tarigans. 2011. Pengembangan Usahatani Cengkeh Berbasis Pendapatan Melalui Penerapan Teknologi yang Berwawasan Pengurangan Kemiskinan Petani Kelapa di Indonesia. Pusat Penelitian dan Pengembangan Perkebunan. Jurnal Ilmiah Pusat Penelitian danPengembangan Perkebunan Indonesia Volume 11 nomor 1 Hal 1 - 3. Medan.
Tohir. 2003. Seuntai Pengetahuan Usahatani Indonesia. PT. Rineke Cipta. Jakarta.

Wilson. 2007. Perencanaan dan Evaluasi Usahatani. PT Remaja Rosdakarya. Bandung.

Wokas. 2002. Pengembangan Usahatani cengkeh dan Aplikasinya. Jurnal Ilmiah Balai Penelitian Tanaman Tahunan Indonesia Timur Volume 12 nomor 1 Tahun Ketiga. Hal 4- 6. Manado. 